\title{
Nationality Versus Global Citizenship Towards the Realization of Sustainable Development Goals: Ahmadou Kourouma's Perspective
}

\author{
Kodah, Mawuloe Koffi, PhD \\ Addo-Danquah, Ofosu \\ University of Cape Coast, Ghana
}

Doi: 10.19044/esj.2018.v14n14p61 URL:http://dx.doi.org/10.19044/esj.2018.v14n14p61

\begin{abstract}
In the face of the fast depletion of natural resources worldwide resulting from industrial and economic cannibalism, selfishness and marginalization are becoming more and more pronounced in a globalizing world. The phenomena of selfishness and marginalization are manifest in the introduction of stringent immigration laws by most industrialized countries in the North to ward off migrants from the less developed economies in the South; and also the reinforcement of existing laws by the latter to protect their citizens and natural resources in recent years. Issues of national identity, territorial integrity as against the centrality of humanity remain an Achilles heel toward the attainment of the Sustainable Development Goals (SDGs). As far as 1968, Ahmadou Kourouma, an Ivorian novelist, in his very first narrative text, "Les Soleils des Indépendances" later translated into English as The Suns of Independence, raised the tragic dilemma of national identity at the expense of 'human identity'. In the absence of concrete steps to address the issues over the years, Liberia, Sierra Leone and La Côte d'Ivoire were engulfed in intestine civil strife over two decades later. The main causes of this strife are found in the irrational quest for self-identity in the name of nationality and ethnic superiority for greater access and control of "national" resources. This paper examines the upsurge of socioeconomic and political exclusion, and the potential threats they pose to the realization of the recently launched Sustainable Development Goals. It is done through a critical reading of Kourouma's The Suns of Independence, Allah is not obliged and 'Quand on refuse, on dit non'. The study is posited within the analytical framework of literary studies and sociocriticism.
\end{abstract}

Keywords: Identity; global citizenship; goals; nationality; sustainable 


\section{Introduction}

Considering the rapid diminution of natural resources worldwide as a result of industrial and economic cannibalism, selfishness and marginalization are becoming more and more prominent in a fast globalizing world. The phenomena of selfishness and marginalization are manifest in the introduction of stringent immigration laws by most industrialized countries in the North prevent migrants from the less developed economies in the South from invading their territories as economic predators. These measures are further marked in recent years by the reinforcement of existing laws by countries in the North to protect their citizens and natural resources. In the face of these realities, it is obvious that issues of national identity, territorial integrity akin to these challenges, as against the centrality of humanity, remain an Achilles heel toward the attainment of the recently promulgated Sustainable Development Goals (SDGs), which according to Osborn et al. (2015),

[...] are intended to be universal in the sense of embodying a universally shared common global vision of progress towards a safe, just and sustainable space for all human beings to thrive on the planet. They reflect the moral principles that no-one and no country should be left behind, and that everyone and every country should be regarded as having a common responsibility for playing their part in delivering the global vision.

The above extract emphasizes the universal need for inclusiveness, justice and equity for the sustainability of humanity as a whole. This is a counter-discourse to the reality of selfishness and marginalization resulting in social exclusion, which has characterized humanity faced with scarcity of natural resources, as a major problem to sustainable human development globally. This concern is the running theme in most of Ahmadou Kourouma's narrative texts. Three of the most representative of the texts have been selected to provide primary textual data for this study on the topic "Nationality versus Global Citizenship towards the Realisation of Sustainable Development Goals: Ahmadou Kourouma's Perspective". These are "Les Soleils des Indépendances" (1968/70), “Allah n'est pas obligé” (2000), and "Quand on refuse on dit non" (2004).

The three narrative texts relate the tragedy resulting from selfishness in the name of national identity in La Côte d'Ivoire, Liberia and Sierra Leone which serve as setting for the stories. The first two texts are translated into English as The Suns of Independence and Allah is not obliged respectively. Consequently, quotations will be taken from both versions as the case may require, in the case of these first two. Concerning the third text, Quand on refuse on dit non, quotations will be taken from the existing version in the French language. These will be translated and commented on in the study. 


\section{Overview of the narrative texts}

In The Suns of independence, Kourouma, through his main character Fama Dumbuya, deplores the ills of social exclusion occasioned by the establishment of unfair socio-economic and political practices in the newly independent fictional States of Ebony Coast and The People's Republic of Nikinai germane to modern day La Côte d'Ivoire and Guinea Conakry, respectively. Dramatizing the long standing dichotomy between capitalism and socialism, developed and underdeveloped, modernity and tradition, North and South, which is the inherent characteristic of the dualistic world order in this narrative, Kourouma fashions out a harmonious linguistic alloy out of standard French and his native Malinke languages. This linguistic alloy brings to the fore the evils of social exclusion while echoing the significance of social inclusion arising out of a symbiotic coexistence in a borderless world to sustainable human development and equitable humanistic world order in an effort to attain the Sustainable Development Goals (SDGs). This is clearly demonstrated through Fama's persistent fight against the introduction of national identification cards and balkanization of the dated kingdom of Horodougou into the modern states of Ebony Coast and the People's Republic of Nikinai respectively. The tragic demise of Fama at the end of the narrative points to the futility of selfishness and egocentric extremism.

In the case of Allah is not obliged, Kourouma decries the carnages of civil strife resulting from selfishness and irrational pursuit of socio-economic and political power and self-aggrandisement. This inordinate pursuit takes various irrational forms which compromise the sustainability of humanity. The linguistic deconstruction which characterizes the language of Birahima, the child-soldier-narrator in the story, is a vivid testimony of the threat of nationalism, a manifestation of selfishness on a larger scale of marginalization and exclusion, to global citizenship, which reflects Kourouma's perspective on the creation of an equitable and just socio-economic and political world order, anchored on a great sense of humanity and fellow-feeling.

Quand on refuse on dit non is a reflective account of Birahima, an exchild-soldier, on the Ivoirian civil war sparked by the senseless and irrational issue of "ivoirité" emanating from an obnoxious exclusionist political ploy which seeks to challenge the citizenship of a section of the people so as to marginalize them and jettison them from the mainstream of socio-economic and political development of their society and country. Birahima, the childsoldier-narrator in Allah is not obliged, leaves "le pays sauvage et barbare du Liberia" (Kourouma, 2004:13) for his native country la Côte-d'Ivoire, having had enough of the tribal wars in Liberia and Sierra Leone, only to be embroiled in another civil war. He intimates:

Après les guerres tribales du Liberia et de Sierra Leone, je croyais que c'était le comble (signifie le summum, l'apogée). 
Non, le bordel dans la merde au carré continue. Me voilà perdu et vagabondant dans les massacres et les charniers barbares de la Côte-d'Ivoire. (Kourouma, $2004: 14$ )

When the Liberian and Sierra Leonean tribal wars ended, I thought that was the height of all (meaning the peak, the apogee). No, the shambles in the shit continues. Here am I lost and wandering through the barbarous massacres and mass graves of la Côte-d'Ivoire. (Our translation)

It is in this dazzling circumstance that Birahima falls in love with Fanta, an intelligent and pretty young daughter of an Imam, and agrees to accompany her to the rebels' territory. She recounts to him the history of their country. This story is the last sound of Kourouma's vibrating and colorful voice, as the text was published a year after his demise.

The paper examines some themes and Kourouma's language in relation to marginalization, education and ideologies in the three narratives in order to unveil what it considers as Kourouma's perspective on the issues of nationality and global-citizenship towards the realization of the SDGs. The study is carried out within the conceptual framework of literary studies and sociocriticism. It is primarily based on textual data collected from the three afore-mentioned narrative texts of Kourouma, and the Sustainable Development Goals as promulgated by The United Nations Organization. First and foremost, it proposes an overview of the list of the seventeen (17) UN Sustainable Development Goals christened the 17 SDGs. Subsequently, it examines the themes of the of identity, socio-economic and political exclusion, and the style through which Kourouma's perspective relating to the Sustainable Development Goals appears to find expression in the three texts. The selected narrative texts for the study will be referred to as The Suns, Allah and 'Quand on refuse' respectively in the subsequent parts of the paper.

\section{Overview of Sustainable Development Goals}

The Sustainable Development Goals [SDGs] are the new United Nations international development agenda to be realized by the year 2030. They replace the hitherto Millennium Development Goals (MDGs). Whereas "the MDGs set out goals for developing countries to which rich countries added assistance through finances and technology, [...] the SDGs are 'universal goals' that apply to all countries and 'involve the entire world, developed and developing countries alike, taking into account different national realities." (2015: 10). Highlighting the expectation on the SDGs, the expects comment thus:

The 17 Sustainable Development Goals form a cohesive and integrated package of global aspirations the world commits to achieving by 2030 . Building on the achievements 
of their predecessors the MDGs, the SDGs address the most pressing global challenges of our time, calling upon collaborative partnerships across and between countries to balance the three dimensions of sustainable development economic growth, environmental sustainability, and social inclusion.

They are concisely encapsulated in the following terms:

Goal 1: End poverty in all its forms everywhere

Goal 2: End hunger, achieve food security and improved nutrition and promote sustainable agriculture

Goal 3: Ensure healthy lives and promote well-being for all at all ages

Goal 4: Ensure inclusive and equitable quality education and promote lifelong learning opportunities for all

Goal 5: Achieve gender equality and empower all women and girls

Goal 6: Ensure availability and sustainable management of water and sanitation for all

Goal 7: Ensure access to affordable, reliable, sustainable and modern energy for all

Goal 8: Promote sustained, inclusive and sustainable economic growth, full and productive employment and decent work for all

Goal 9: Build resilient infrastructure, promote inclusive and sustainable industrialization and foster innovation

Goal 10: Reduce inequality within and among countries

Goal 11: Make cities and human settlements inclusive, safe, resilient and sustainable

Goal 12: Ensure sustainable consumption and production patterns

Goal 13: Take urgent action to combat climate change and its impacts

Goal 14: Conserve and sustainably use the oceans, seas and marine resources for sustainable development

Goal 15: Protect, restore and promote sustainable use of terrestrial ecosystems, sustainably manage forests, combat desertification, and halt and reverse land degradation and halt biodiversity loss

Goal 16: Promote peaceful and inclusive societies for sustainable development, provide access to justice for all and build effective, accountable and inclusive institutions at all levels

Goal 17: Strengthen the means of implementation and revitalize the global partnership for sustainable development

A critical observation of the above goals set by the World body falls within Kourouma's concerns as articulated in his fictional works. The SDGs in actual fact reflect the themes and style of his narrative tests. These goals indeed give credence to the social-economic and political issues that informed Kourouma's literary artistry and run through his texts. It is in this respect that 
his perspective toward their concrete realization becomes a topic for critical study in this paper. The subsequent paragraphs examine the thematic issues of the quest for identity and Kourouma's inclination toward social inclusion toward global citizenship required for the realization of the SDGs.

\section{Quest for identity}

Identity represents the characteristic features that distinguish an individual from the rest of the same kind. It also defines the "sense of who one is" vis-à-vis the other. The quest for identity is therefore both a psychological and physical effort in pursuit of selfhood at the expense of the other. The quest for identity results from an awareness of a lost identity and self-esteem, and the ardent desire to regain same. It manifests itself at different level: individual, group or corporate levels. This is found with phrases such as selfidentity, corporate identity and national identity. The quest for identity can also be tagged to ethnicity, culture, religion and many other considerations in relation to people's belief, persuasion, profession and origin. In all these instances, the driving force is the desire for acceptance, recognition and (re)integration into the mainstream of society.

Irrespective of what forms it assumes, the quest for identity is a manifestation of discontentment fueled by frustration and anger over a state of marginalization and injustice. Conflict and violence are therefore inherent characteristics of this human pursuit.

\section{National identity}

Nationality refers to an identity between a person and a nation, and the right to work, live and participate politically in a particular geographical area. It is often used as "a synonym for citizenship in English - notably in international law - although the term is sometimes understood as denoting a person's membership of a nation which is a large ethnic group". (online source). Identity on the other hand refers to defining characteristics that distinguish one person from another, one species from another kind. It stands for features that mark off one kind from another.

National identity is therefore one's identity or sense of belonging to one state or to one nation. It is the sense of a nation as a cohesive whole, as represented by distinctive traditions, culture, language and politics. National identity may refer to the subjective feeling one shares with a group of people about a nation, regardless of one's legal citizenship status. National identity is viewed in psychological terms as "an awareness of difference", a "feeling and recognition of 'we' and 'they'". (online source).

The expression of one's national identity seen in a positive light is patriotism which is characterized by national pride and positive emotion of love for one's country. The extreme expression of national identity is 
chauvinism, which refers to the firm belief in the country's superiority and extreme loyalty toward one's country. (ibid.)

Be it patriotism or chauvinism, the quest for identity is invariably a self-centered and egocentric venture which pitches an individual against another. Kourouma's abhorrence for segregation of humanity and balkanization of planet earth into countries, races, regions, etc. is forcefully articulated in The Suns, Allah and "Quand on refuse" around the main themes and the various characters.

Kourouma's rejection of divisive tendencies and marginalization which characterize the emergence of modern states in the wake of independence from French colonialists, coupled with debilitating and dislocating social, economic and political impact, in The Suns is woven around the expressed frustration of the characters of Sery, a driver's assistant on one hand, and Fama, the last descendant of the Dumbuya princes, the main character, on the other hand.

Sery appears in the opening chapter of Part Two of the narrative. He is on board the truck Fama boards on his journey to Togobala. According to the narrator's cynical comment in introducing him, "He, Sery, knew the secret of peace and happiness in Africa." (The Suns: 58). Kourouma uses Sery's simplistic xenophobic discourse to unveil his abhorrence of division and socio-economic and political exclusion. Pretending to know the root causes of conflicts in Africa, Sery, a mere driver's assistant, poses a question to which he quickly provides his preconceived and premeditated answer: "Do you know what causes wars and misery in Africa? Well, it's quite simple; it's because Africans don't stay at home". (The Suns: 59). Feigning to share in Sery's xenophobic stance, the narrator intimates:

He himself had never left the Ebony Coast to settle in another country and deprive its inhabitants of work, whereas other people had come to his country. The French colonizers brought along people from Dahomey and Senegal, who knew how to read and write and were French citizens or else Catholics; smarter, more civilized, harder-working Africans than the native inhabitants of the country, who belonged to Sery's tribe. (ibid.)

Sery therefore goes further to expatiate his thesis in justification his xenophobic proclivity in the following words:

The white colonizers gave them all the jobs and all the money, and with that money the Dahomeyans bedded our girls, married the prettiest ones, took over our best land, lived in the tallest houses; they cut our children's throats as offerings to their fetishes, and French justice didn't interfere because they themselves were the judges and lawyers. Whenever there was 
a new post created, they brought someone from Dahomey to fill it, and whenever someone was sacked or out of work, it was always one of our own people. This was how it was, (...) the Europeans on top, then the Dahomeyans and Senegalese, and we were just nothing, lying underfoot. (The Suns: 59)

Much as Sery's status as a driver's mate makes most of the issues his simplistic submissions in the above quotation quite questionable, it is obvious that he and his likes feel marginalized and denied recognition in the socioeconomic affairs of their country. Out of deep seated animosity, “.... as soon as Independence came, the Sery rose up and attacked the Dahomeyan" (ibid.) to demand their pound of flesh. He heartily recounts below how they proceed:

First we took back our women, then we beat their children and raped their sisters before their very eyes, before plundering their goods and setting their houses on fire. Then we chased them down to the shore. We wanted to drown them, to see the waves wash them ashore with swollen bellies, unrecognizable, like dynamited fish. (ibid.)

But for the timely intervention of French troops, the Sery would have exterminated all the Dahomeyans and Senegalese. He intimates: "Luckily for them the French troops intervened, herded them into the harbor and guarded the entrance with tanks. So the Dahomeyans boarded ship and left" (ibid.).

The xenophobic atrocities deployed by the Sery on fellow human beings in defense of their national socio-economic rights as citizens of the Ebony Coast, are projected by them as solution to their economic woes. Thus, according to Sery, "Once they [the Dahomeyans] had left and independence had come, the country was really in fine shape. There were jobs and houses for everyone". However, not too long after, the Sery come to the realization that more jobs and houses are needed to meet the growing demand of all. This shows how unreasonable their resort to xenophobic attacks to address issues of socio-economic marginalization and national identity are. The need arises therefore for further action, this time against the French, having driven the Dahomeyans and Senegalese. "So our students and intellectuals said we should get rid of the French; that would bring us a lot more in the way of houses, goods, and money" (ibid.).

However, taking cognizance of their visible vulnerability in the face of the armed French troops, they withdraw strategically, as he recounts in the following lines: "But that was difficult, because of the French troops; besides, it wouldn't have been a good thing, because without the French there would be no jobs and we were tired of being out of work" (ibid.).

Rational thinking brings the Sery to realize the usefulness of tolerating the French. This is going to provide them with jobs that will enable them integrate the mainstream of socio-economic and political life. Subsequently, 
they turn away from the ill advice of their so-called students and selfish intellectuals.

In the case of Fama, he is confronted with an unprecedented mandatory requirement of a national identity card by a custom officer to travel from the capital of the Ebony Coast to Togobala, his birth place, the capital of the great kingdom of Horodougou, the land of his proud ancestors who form the Dynasty of the Dumbuya.

They came to the last village of the Ebony Coast; beyond it, before entering the Socialist Republic of Nikinai, was a customs post. There Fama gave way to a fit of rage, the kind that makes a serpent tremble like a leaf, its throat choked with insults left un-spat. A bastard, a real one, a shameless forest brat whose mother surely never knew a scrap of loincloth nor the married state, dared to stand there on his own two testicles and say that Fama, a foreigner, could not pass without an identity card! (The Suns: 69).

That Fama, the last legitimate Dumbuya prince of the great kingdom of Horodougou, is considered a foreigner in the land of his ancestors is an affront to his dignity and royal lineage. The narrator exclaims, feigning surprise, "Did you hear? Fama a foreigner on the soil of Horodougou!" (ibid.). Fama reacts spontaneously to what appears a condescending treatment, by ordering "him to repeat what he said" (ibid.) The crude reality is that the traditional homeland of Fama's royal ancestry, the great kingdom of Horodougou, is now partitioned between the Republic of Ebony Coast and the People's Republic of Nikinai. The former is capitalist oriented, whereas the latter is socialist inclined. What this really means for Fama's identity becomes a substantial source of both psychological and physical confusion and frustration for him.

The present underlining realities confronting Fama in the face of the physical as well as ideological rending of the homeland of his ancestors fly in the face of historical facts to which he is fervently attached. These facts define his identity as a blue-blooded Malinke, who must not be treated shabbily by a "bastard", "a shameless forest brat" of a customs officer who dares call him a "foreigner" and ask him to produce "an identity card" to enable him cross the customs post between the Ebony Coast and the People's Republic of Nikinai.

In contrast with what happens in The Suns, the quest for identity which underlies the internecine wars in Liberia and Sierra Leone is premised on tribal hegemony fuelled by the megalomaniac pursuits of irrational individuals and politicians in Allah. According to the child-soldier-narrator,

In Liberia, there were four big important warlords: Doe, Taylor, Johnson and the Hajji Koroma, as well as a bunch of small warlords. The small warlords were doing their best to be 
big warlords. And everything in the whole country had been divided up. That's why we say there was tribal wars in Liberia. (Allah: 43 - 44)

Similarly, "Sierra Leone is a fucked-up mess, a big-time fucked-up mess" (pp. 157). What does the child-soldier-narrator mean by a "fucked-up mess"? He explains further: "A country is a fucked-up mess when you get warlords dividing it up between them like in Liberia, but when you've got political parties and democrats on top of the warlords it's a big-time fuck-up mess" (ibid.). He explicates he means by "a big-time fucked-up mess", when he continuous thus:

In Sierra Leone, the Kamajors (the hunters' militia) and Kabbah (the democrat) were embroiled in everything, along with warlords like Foday Sankoh, Johnny Koroma and some small-time bandits. That's why people say Sierra Leone isn't a mess, it's a big-time fucked-up mess. In pidgin, the Kamajor are called 'the respectable association of professional traditional hunters' (ibid.).

The above quotations from Allah also bring to the fore the devastating nature of selfish pursuit in the name of tribal and political bigotry as decried by Kourouma through the satirical voice of the child-soldier-narrator. The combined effect of the naivety of a child and the lucidity of an adult in the child-soldier-narrator in this text is quite an effective stylistic detour for Kourouma's denunciation of the underlying socio-economic and political ills which are inimical to the attainment of the SDGs.

The issues of self and national identity as problematized and denounced in The Suns, published for the first time in 1968 in Canada, and subsequently in 1970 in France, remain unresolved and define the central theme which is the underlining cause of the Ivorian civil strife in Quand on refuse, published in 2004, the policy of -"ivoirité". The irrational and reprehensible concept of "ivoirité" seeks to exclude Ivorian citizens of northern extraction who have over the years laboured in all sectors of human development to build the South from mainstream politics by denying them citizenship rights through an obnoxious legal regime. According to the narrator, the South has been built through the mobilization of labour from the North.

C'est la main d'œuvre du Nord mobilisée dans le cadre des travaux forces qui a bâti le Sud. C'est elle qui a bâti les routes, les ports, les chemins de fer, les bâtiments du Sud. Parce que les habitants de la forêt étaient considérés comme lymphatiques. [...] C'est parce que les habitants de la forêt étaient considérés comme lymphatiques que les Dioulas sont morts comme des mouches pour construire le Sud. Il n'y a 
aucune pierre, aucune brique, aucun pont, etc., du Sud qui n'ait été bâti par des mains de Dioulas du Nord. (p. 65)

The South was built through labour mobilized from the North within the framework of forced labour. It was that labour that built the routes, the ports, the railways, the buildings in the South. Because the people of the forest were considered as lymphatic. [...] It's because the people of the forest were considered lymphatic that the Dioula people perished like house flies to build the South. There isn't one stone, one brick, one bridge, etc., in the South which hasn't been built by Dioula hands from the North. [Our translation]

In spite of these records, the Dioula of the North whose blood and toils have built all that there is that makes Ivory Coast a prosperous country, are delegitimized and marginalized as aliens in the land of their birth through the ideology of ivoirité. This is made more lucid in the following quotation:

L'ivoirité est le nationalisme étroit, raciste et xénophobe qui naît dans tous les pays de grande immigration soumis au chômage. Partout, c’est une idéologie prêchée par des intellectuels marginaux et qui est adoptée par une couche marginale de la population. En Côte-d'Ivoire, l'idéologie de l'ivoirité devient la doctrine de l'État. p. 107

Ivoirite is the narrow, racist and xenophobic nationalism born in every country which is great destination for migrants faced with unemployment challenges. Everywhere, it is an ideology preached by marginal intellectuals and adopted by a marginal section of the population. In Ivory Coast, the ideology of ivoirité becomes the State doctrine. [Our translation]

This irrational egocentric political ideology, which defies all reasons and historical facts, consequently plummets the entire country into chaos. It gets the country divided between South and North, marked by bitter political rivalry between Konan Bédié and Alhassan Ouattara, following the demise of President Félix Houphouët-Boigny. The persistent political rivalry and powerplay among the various political actors deepens the South-North divide and heightens the level of marginalization of a section of the Ivorian people based on ethnic considerations. Bédié, who succeeds Houphouët-Boigny as the second democratically elected President of Ivory-Coast, fails to unite the country afflicted by such divisions which the narrator clarifies in the following words: "Bédié oubliait que le pays était une mosä̈que hétéroclite de races et de tribus dont l'unité restait à faire. Les peuples se trouvaient assemblés dans les limites imposées par la colonisation et maintenues sous les férules de la guerre froide." As the narrator intimates, "Bédié forgot that the country was a mosaic of heterogeneous races and tribes which remain to be unified. The 
people were found put together within boundaries imposed by colonization and maintained in place under the iron rule of Cold War." [Our translation].

Evidence adduced from all the quotations from the three narrative texts points to the existence of socio-economic and political exclusion as well as its nefarious consequences. Judging from the call for global inclusion, tolerance and humanistic collaboration and interrelation that cuts across the SDGs, it is obvious that the world body has really identified the failures of the exclusionist ideologies which have engendered to socio-economic and political strife across the globe over the centuries; hence, the need for a more human-centred approach toward attaining real sustainable development for humanity in its entirety. Kourouma's perspective points to the same direction; the direction of human-centred reforms to address the sustainable development needs of humanity. Reforms geared toward the creation of global citizens whose actions and inactions will transcend national, regional, religious, ethnic and tribal restrictions.

\section{Toward global citizenship}

What then is the way to attaining this global citizenship? The descriptive adjective 'global' refers to the entirety of a phenomenon relating to the globe or concerning all parts of the world. Citizenship is the status of a person recognized under the custom or law as being a member of a sovereign state. This status confers on a person rights, responsibilities and duties that come with being a member of our global community/world.

"Global citizenship" is aptly put as a concept that assumes many forms and it is highly dependent on the particular context in which it is used" (M. Brigham, 2011: 2). It implies taking responsibility for and getting actively involved in global issues. For the Atlantic Council for International Cooperation, it is defined in the following terms:

Global citizenship is a way of understanding how the world works, links between our own lives and those of people throughout the world. A way of seeing social justice and equity, other people's reality, diversity, inter-connectedness, and the way that people can make a difference. A way of acting exercising political rights, critical thinking, and challenging injustice.

A global citizen is therefore "someone who identifies with being part of an emerging world community and whose actions contribute to building this community's values and practices." (online source). This status confers on a person rights, responsibilities and duties that come with being a member of our global community/world. Global citizenship typically defines a person who places his identity with a "global community" above his identity as a citizen of a particular nation or place. The idea is that, one's identity transcends 
geographical or political borders and that, responsibilities or rights are or can be derived from membership in a broader class: "humanity". Global citizenship embraces and extols "the idea that human identity transcends geographical or political borders and that the planetary human community is interdependent and whole; humankind is essentially one".

Conceptually, Global citizenship, in some contexts, may refer to a brand of ethics or political philosophy in which it is proposed that the core social, political, economic and environmental realities of the world today should be addressed at all levels - by individuals, civil society organizations, communities and nation states - through a global lens. It refers to a broad, culturally - and environmentally-inclusive worldview that accepts the fundamental interconnectedness of all things. Political, geographic borders become irrelevant and solutions to today's challenges are seen to be beyond the narrow vision of national interests. (online source)

Kourouma's tacit prescription of socio-economic and political inclusion, tolerance and equity as a humanistic approach to the veritable realisation of the Sustainable Development Goals permeates his linguistic artistry in the three narrative texts. Through a harmonious combination of the standard French language and his native Malinke language in these texts, Kourouma creates a harmonious textual setting where respect and tolerance for divergence in a peaceful symbiotic coexistence of French and Malinke lexical items, syntactic structure and cultural persuasions thrive.

The constant use of parenthetical constructions in the texts and of four dictionaries for the child-soldier-narrator in Allah in particular is a clear attempt to remove any form of ambiguity from the combination of the various languages and cultural indices, so as to make the understanding of the new symbiotic language accessible to all. Kourouma's experience is therefore presented as a reflection of his perspective for a global citizenship.

\section{Conclusion}

Notwithstanding the fact that Kourouma's narrative texts predate the formulation and promulgation of the United Nation's Sustainable Development Goals [SDGs], the latter provides justification for his concerns for humanity to work closely toward the creation of a more humane, just and equitable inclusive society universally. Conflicts across the globe are mainly linked to exploitation, rejection and exclusion. The actual realisation of the SDGs therefore depends invariably on the deployment of effective measures to address socio-economic and political exploitation in every human society. This requires purposeful humanistic strategies geared toward reforming the dated empire-mindset of the industrialised and so-called powerful nations.

Empowering people through dialogues, teamwork, equitable sharing of the fruits of the collective labour of everybody, and acknowledging the 
sharing of a common humanity among all the people of the world is the most effective way to attaining the laudable objectives of the SDGs. Kourouma's literary texts studied in this paper amply reveal the extent to which exploitation and marginalisation have nurtured latent frustrations and turned them into destructive energies in the characters. Denouncing these phenomena in the texts, Kourouma harmoniously forges a symbiotic relationship between his native Malinke language and the French language. Out of this symbiotic linguistic textual upholstery, Kourouma extols the virtues of collaborative partnership, inclusive education, tolerance of dissent and diversity in the pursuit of the collective goods, at the expense of individual, selfish and egoistic interest.

In Kourouma's eyes, through a reflective reading of the texts, these approaches are the sure paths to sustainable human development. Harnessing and harmonising cultural diversities in a kind of a melting-pot of humanity will lead to the production of global-citizens. This process will result in, to paraphrase Armah (2010), remembering a dismembered humanity, for the sustainability of planet earth. It will generate a new development ideology informed by the centrality of the interest of the collective rather than the individual. The evolving human-centred ideology will help to harness the collective energy of the global-citizens as a driving-force for the ultimate realization of the aspirations of the framers of the SDGs. In the absence of such steps, the SDGs will remain mere a lip-service paid to well-intentioned dreams for the sustainability of humanity by 2030 .

\section{References:}

1. Armah, A. K. (2010). Remembering the dismembered continent: Essays. Popenguine. Senegal: Per Ankh.

2. Atlantic Council for International Cooperation, Halifax. (no date).Global Citizen's Guide. Www.aciccaci.org/pdf/Global_Citizen_Guide-pdf [Consulted 01/09/2016]

3. Brigham, M. (2011). "Creating a Global Citizenship and Assessing Outcomes”. Journal of Global Citizenship \& Equity Education. Volume 1, Number 1. www.journals.sfu.ca/jgcee

4. Getting Started with the Sustainable Development Goals: A Guide for Stakeholders. Sustainable Development Network. A Global Initiative for the United Nations. December, 2015. www.unsdsn.org/

5. Global citizenship. www.en.wikipedia.org/wiki/Global_citizenship [Consulted 31/08/2016]

6. Kourouma, A. (1970). Les Soleils des Indépendances. Paris : Editions du Seuil.

7. Kourouma, A. (2000). Allah n'est pas obligé. Paris : Editions du Seuil. 
8. Kourouma, A. (2004). Quand on refuse on dit non. Paris : Editions du Seuil.

9. Kourouma, A. (1970). Les Soleils des Indépendances. Translated by Adams, A. (1982). The Suns of Independence. London: Heinemann Educational Books Ltd.

10. Kourouma, A. (2000). Allah n'est pas obligé. Translated by Wynne, F. (2006). Allah is not obliged. London: Vintage Books.

11. Osborn, D., Cutter, A. \& Ullah, F. (2015). Universal Sustainable Development Goals: Understanding the Transfomational Chalenge for Developed Countries. Report of A Study by Stakeholder Forum. www.stakeholderforum.org [Consulted 31/08/2016]

12. The United Nations. (2014). Open Working Group proposal for Sustainable Development Goals. https://sustainabledevelopment.un.org/content/documents/1579SDGs \%20Proposal.pdf [Consulted 31/08/2016] 